\title{
Zaczyny cementowe $z$ dodatkiem nanokomponentów do uszczelniania kolumn rur okładzinowych w otworach wiertniczych o głębokości końcowej około 1000-2000 metrów
}

\section{Cement slurries with the nanocomponents for sealing casing columns in boreholes with a final depth of 1000-2000 meters}

\author{
Marcin Rzepka, Miłosz Kędzierski \\ Instytut Nafty i Gazu - Państwowy Instytut Badawczy
}

\begin{abstract}
STRESZCZENIE: Tak jak w każdej dziedzinie nauki, tak również w wiertnictwie konieczne jest stałe dążenie do tworzenia nowych, zmodernizowanych produktów. Dlatego też zarówno na świecie, jak i w Polsce trwają nieprzerwanie badania mające na celu uzyskanie trwalszych, szczelniejszych czy też bardziej ekologicznych materiałów wiążących. Coraz częściej poszukiwane są innowacyjne rozwiązania, które pozwolą na otrzymywanie jak najwyższej klasy produktów wiążących. Ostatnio synonimem rozwoju i postępu stała się nanotechnologia - dynamicznie rozwijający się dział nauki zajmujący się zarówno projektowaniem, tworzeniem, jak i badaniem struktur o wielkości rzędu nanometrów (miliardowych części metra). Kamień cementowy utworzony jest m.in. z małych ziaren uwodnionych krzemianów wapnia i dużych kryształków uwodnionych produktów hydratacji, między którymi znajdują się przestrzenie porowe. Jest to miejsce, w którym mogą się z powodzeniem upakować drobne ziarenka nanocząsteczek, powodując zmniejszenie porowatości i przepuszczalności matrycy cementowej. W artykule zamieszczono wyniki badań przykładowych receptur zaczynów cementowych (zawierających od $0,5 \%$ do $1 \%$ nanokrzemionki) przeznaczonych do uszczelniania kolumn rur okładzinowych w otworach wiertniczych o głębokości końcowej około 1000-2000 metrów. Receptury zaczynów opracowano w INiG - PIB. Zaczyny posiadały gęstość około $1870 \mathrm{~kg} / \mathrm{m}^{3}$, a ich czasy gęstnienia dobrano odpowiednio do danych warunków geologiczno-technicznych. Próbki kamieni cementowych uzyskane z zaczynów z nanokomponentami cechowały się bardzo niską (jedynie około 2\%) zawartością porów kapilarnych. Pory o najmniejszych rozmiarach (poniżej $100 \mathrm{~nm}$ ) stanowiły zdecydowaną większość (powyżej 95\%) ogólnej ilości porów występujących w matrycy cementowej, co świadczy o bardzo niskiej przepuszczalności dla medium złożowego. Wczesne wytrzymałości na ściskanie wynoszące 3,5 MPa (na podstawie badania na ultrasonograficznym analizatorze cementu) zaczyny uzyskiwały po czasach od około 71/2 godziny do 14 godzin. Po tym okresie kamień cementowy jest na tyle mocny, że możliwe jest dalsze prowadzenie prac w otworze. Wytrzymałości na ściskanie kamieni cementowych po 28 dniach hydratacji przyjmowały bardzo wysokie wartości, dochodzące nawet do $38 \mathrm{MPa}$ (wytrzymałości te znacznie przekraczały wyniki uzyskiwane dla zaczynów konwencjonalnych). Przyczepność do rur stalowych po 28 dniach hydratacji była bardzo wysoka i wyniosła około 6 MPa. Potwierdzeniem niezwykle zwartej mikrostruktury próbek $\mathrm{z}$ nano- $\mathrm{SiO}_{2}$ mogą być fotografie próbek zaczynów wykonane za pomocą mikroskopii skaningowej. Widać na nich zbitą matrycę cementową o bardzo małej przepuszczalności.
\end{abstract}

Słowa kluczowe: nanokrzemionka, zaczyn cementowy, stwardniały zaczyn cementowy, wytrzymałość mechaniczna.

ABSTRACT: As in every field of science, drilling also requires a constant effort to develop new, modernized products. Both in the world and in Poland research is therefore continually under way to obtain more durable, tighter or more ecological binding materials. Innovative solutions are increasingly being sought to produce the highest quality binding materials possible. Recently, nanotechnology has become a synonym for development and progress - a dynamically developing branch of science, dealing with both designing, creating and testing nanometer-scale (billionths of a meter) structures. Cement stone is formed, among others, from small grains of hydrated calcium silicates and large crystals of hydrated hydration products between which there are pore spaces. It is a place where fine grains of nanoparticles can be successfully packed, causing a decrease in the porosity and permeability of the cement matrix. The article presents the results of testing cement slurries (containing from $0.5 \%$ do $1 \%$ of nanosilica) for sealing the casing columns in boreholes with a final depth of about 1000-2000 meters. Laboratory tests of cement slurries were carried out at Oil and Gas Institute - NRI, developing groups of cement slurry recipes with a density of approximately $1870 \mathrm{~kg} / \mathrm{m}^{3}$. Cement slurries had thickening times properly matched to given geological and technical conditions. Pore distribution of cement stone samples with nanoparticles were characterized by a small

Autor do korespondencji: M. Rzepka, e-mail: marcin.rzepka@inig.pl

Artykuł nadesłano do Redakcji 14.06.2019 r. Zatwierdzono do druku 11.10.2019 r. 
number of capillary pores (about 2\%). Pores of the smallest sizes (below $100 \mathrm{~nm}$ ), made up a vast majority (over $95 \%$ ) of the total pores in the cement matrix, which prove their low permeability for reservoir fluids. The early compressive strengths of $3.5 \mathrm{MPa}$ (based on an Ultrasonic Cement Analyzer) where obtained after about $71 / 2$ to 14 hours. After this period, the cement stone is strong enough to continue work in the borehole. Compressive strength after 28 days of hydration was very high, reaching even $38 \mathrm{MPa}$ (these strengths were much higher than those obtained for conventional slurries). Adhesion to steel pipes after 28 days of hydration was very high and amounted to about $6 \mathrm{MPa}$. The extremely compact microstructure of the samples with nano- $\mathrm{SiO}_{2}$ is confirmed by scanning electron microscope images of cement samples. They show a compact cement matrix with very low permeability.

Key words: nanosilica, cement slurry, set cement, mechanic strength.

\section{Wprowadzenie}

Nanotechnologia to nowatorska dziedzina nauki zajmująca się m.in. badaniem, projektowaniem i wytwarzaniem komponentów o bardzo małych rozmiarach. Komponenty te posiadają wielkość ziaren rzędu nanometrów, co pozwala na uzyskanie z nich produktów o unikatowych właściwościach technologicznych. Potencjalne możliwości zastosowań tzw. nanomateriałów, tj. materiałów mających choć jedną właściwość, taką jak wymiar cząstki, wymiar porów lub grubość filmu, w przedziale od 1 do $100 \mathrm{~nm}$, są ogromne, a intensywny rozwój nauki w tej dziedzinie sprawia, że pierwsze dekady XXI wieku określane są początkiem ery nanotechnologii.

Spośród szeregu materiałów poddanych modyfikacji za pomocą nanotechnologii można wyróżnić powszechnie znany i używany budulec, jakim jest cement (Horszczaruk et al., 2013). Współcześnie na świecie kładzie się coraz większy nacisk na unowocześnianie kompozycji mieszanin cementowych w celu polepszenia parametrów wytrzymałościowych i fizyczno-chemicznych. W ostatnich latach na rynkach zaczynają się pojawiać innowacyjne produkty określane często nazwą ,nanocementy". Produkty cementowe zawierające nanokomponenty mają cechy trwalszych, bardziej wytrzymałych czy też posiadających znacznie bardziej gładką powierzchnię w porównaniu do produktów wytworzonych z cementów konwencjonalnych. Już małe ilości nanomateriałów zastosowane jako dodatki do zaczynu mogą zagęścić strukturę krystaliczną sporządzanej receptury cementowej, zmniejszyć wielkość porów oraz zredukować ich ilość, a tym samym poprawić wyraźnie parametry technologiczne. Dlatego też szereg ośrodków naukowych na świecie rozpoczęło prace badawcze nad zastosowaniem nanotechnologii m.in. w pracach cementacyjnych prowadzonych podczas uszczelniania naftowych otworów wiertniczych (De La Roij et al., 2012).

W INiG - PIB również podjęto się opracowania innowacyjnych zaczynów cementowych wzbogaconych o dodatek nanocząsteczek krzemionki (nano-SiO ${ }_{2}$ ), które mogą w najbliższych latach być użyte $\mathrm{w}$ procesie uszczelniania rur okładzinowych w otworach wiertniczych na głębokościach około 1000-2000 metrów, gdzie temperatura denna wynosi około $40-60^{\circ} \mathrm{C}$ (Dębińska, 2014, 2015; Dębińska et al., 2016).

\section{Zastosowanie nanokomponentów w wiertnictwie i mechanizm ich działania w zaczynie cementowym}

Badania prowadzone przez zagraniczne ośrodki potwierdzają, że nanotechnologia oferuje możliwości precyzyjnego zaprojektowania składników cementu do specyficznych potrzeb panujących w otworze wiertniczym (Wilk et al., 2014; Uliasz et al., 2015). Literatura podaje przykłady zastosowania nanokomponentów wpływających w znacznej mierze na wzrost wytrzymałości na ściskanie i trwałość oraz szczelność matrycy cementowej. Zauważono, że dodatek nanokrzemionki, poza poprawą właściwości mechanicznych kamieni cementowych, wpływa także w pewnym stopniu na zmniejszenie filtracji. Wytrzymałość na ściskanie i zginanie zaczynu cementowego $\mathrm{z}$ dodatkiem nano- $\mathrm{SiO}_{2}$ okazuje się wyższa niż wytrzymałość konwencjonalnego zaczynu cementowego o podobnym stosunku w/c (Ershadi i Ebadi, 2011). Oprócz zwiększenia wytrzymałości dodatek nanocząsteczek poprawia również zdolność monitorowania naprężeń w kamieniu cementowym. Jak wiadomo, cement jest materiałem porowatym o rozmiarze porów od kilku nanometrów do kilku mikrometrów. Są one głównie wypełnione zasadowym roztworem wapnia rozpuszczonego w wodzie. Dlatego też warunki środowiskowe, charakteryzujące się niższym $\mathrm{pH}$, zakłócają równowagę i są niekorzystne dla betonu. Badania prowadzone przy zastosowaniu metody MAS-NMR (magic-angle spinning nuclear magnetic resonance) wykazały, że dodatek nanokrzemionki do zaczynu cementowego nie tylko wpływa na zwiększenie średniej długości łańcucha żelu C-S-H, ale również powoduje powstawanie wysokosztywnej fazy tego żelu kosztem fazy niskosztywnej, co w znaczący sposób wpływa na wzrost wytrzymałości powstającego kamienia.

Wysokie temperatury i ciśnienia panujące w otworze wiertniczym bardzo często wymagają stosowania szczególnie odpornych zaczynów cementowych, zawierających zaawansowane technologicznie dodatki pomagające uzyskać odpowiednią izolację międzystrefową. Z uwagi na częste adaptowanie w wiertnictwie wielu rozwiązań wykorzystywanych między innymi w praktyce budowlanej można przypuszczać, że w najbliższych latach nanomateriały znajdą zastosowanie 
przy projektowaniu zaczynów cementowych do uszczelniania otworów wiertniczych.

Jak wiadomo, matryca kamienia cementowego zbudowana jest głównie z ziaren uwodnionego żelu krzemianów wapnia i kryształków uwodnionych produktów hydratacji, między którymi znajdują się nanopory i pory kapilarne. Jest to miejsce idealne dla nanocząsteczek, aby poprzez wypełnienie panujących w matrycy pustek zagęścić strukturę zaczynu cementowego. Jednakże z powodu dużej energii powierzchniowej nanocząsteczki łatwo mogą łączyć się w agregaty, co powoduje znaczne trudności w ich dyspersji (zwłaszcza w przypadku większych ilości). W tym przypadku powstawanie agregatów nanocząsteczek prowadzi do tworzenia się pustych przestrzeni, które wpływają na osłabienie właściwości mechanicznych zaczynów cementowych. Aby temu zaradzić, należy odpowiednio ujednorodnić wodę zarobową z nano- $\mathrm{SiO}_{2}$, np. za pomocą sonifikatorów lub mieszadeł wysokoobrotowych.

Mechanizm poprawy zwartości mikrostruktury i wytrzymałości kamieni cementowych można przedstawić w następujący sposób. Kiedy małe ilości nanocząsteczek zostaną równomiernie rozproszone w zaczynie cementowym, produkty hydratacji cementu zaczną się osadzać na nanocząsteczkach ze względu na ich dużą energię powierzchniową i podczas hydratacji będą wzrastać na nich do postaci konglomeratów, zawierających nanocząsteczki jako jądra. Nanocząsteczki zlokalizowane w zaczynie cementowym będą dodatkowo wspierać i przyspieszać hydratację cementu ze względu na swą wysoką reaktywność. Osiągając równomierne rozproszenie nanocząsteczek, można uzyskać odpowiednią mikrostrukturę $\mathrm{z}$ jednorodnie rozproszonymi konglomeratami (Mondal et. al., 2010; Patil i Deshpande, 2012; Santra el al., 2012).

Istnieją trzy możliwe drogi do zwiększenia wytrzymałości kamienia cementowego:

- po pierwsze: nanocząsteczki działają jako jądra/nukleony, mocno wiążące się z hydratami cementu, sprzyjając hydratacji cementu;

- po drugie: nanocząsteczki mogą zapobiegać wzrastaniu dużych kryształków, takich jak $\mathrm{Ca}(\mathrm{OH})_{2}$;

- po trzecie: nanocząsteczki i małe aglomeraty mogą wypełnić pory w kamieniu cementowym (podobnie jak pył krzemionkowy), zwiększając tym samym jego wytrzymałość.
Jest bardzo prawdopodobne, że te mechanizmy odgrywają wiodącą rolę w poprawie wytrzymałości na ściskanie badanych próbek.

Osiągając równomierne rozproszenie nanocząsteczek, można uzyskać odpowiednią mikrostrukturę z równomiernie rozproszonymi konglomeratami.

Na rysunku 1 zamieszczono obrazy wykonane pod mikroskopem skaningowym, na których widać kamienie cementowe bez dodatku nanokrzemionki (kamień bazowy) oraz z dodatkiem nanokrzemionki (Biricik i Sarier, 2014). Powierzchnia próbki bazowego kamienia cementowego (po lewej) charakteryzuje się niejednorodnym rozkładem fazy C-S-H (uwodnionych krzemianów wapnia), ziaren $\mathrm{CH}$ (portlandytu) i kryształów etryngitu, a w strukturze widoczne są mikropęknięcia. Kamień cementowy wzbogacony o dodatek nanotlenku krzemu (po prawej) cechuje się gęściej upakowaną strukturą oraz równomiernym rozproszeniem cząsteczek nanokrzemionki na powierzchni produktów hydratacji. Ponadto ziarna $\mathrm{CH}$ są mniej widoczne niż w przypadku czystego cementu (co wpływa na poprawę trwałości matrycy i zwiększa jej odporność korozyjną).

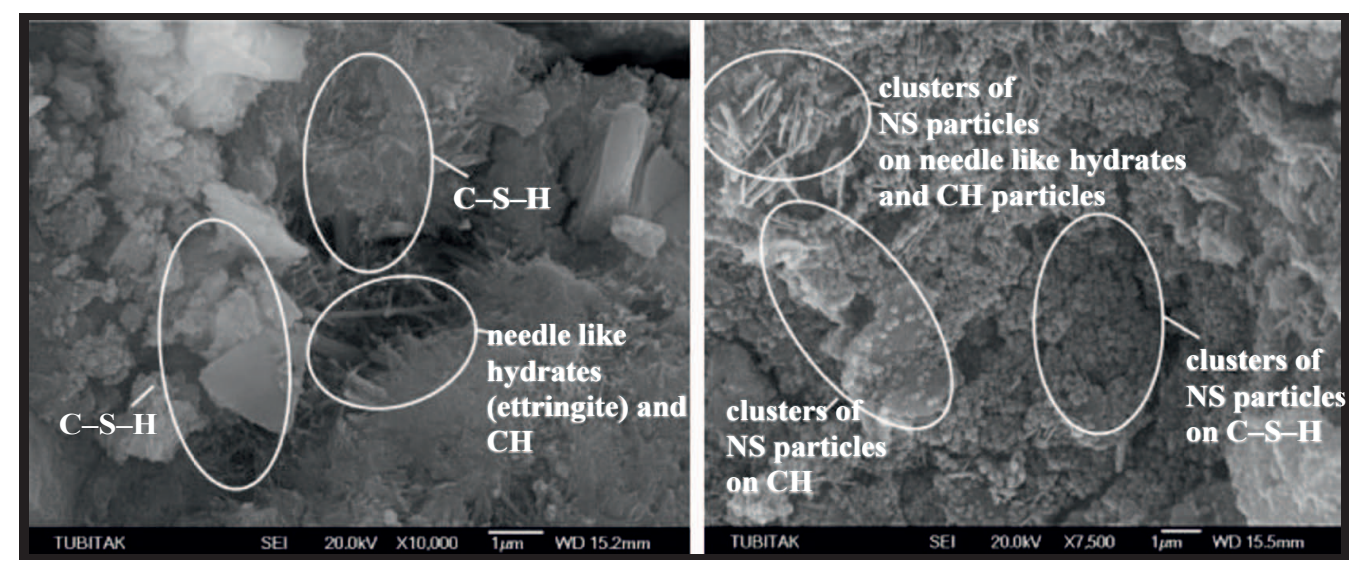

Rys. 1. Fotografia mikrostruktury zaczynu bazowego (po lewej) oraz zaczynu z dodatkiem nano- $\mathrm{SiO}_{2}$ (po prawej) po 7 dniach hydratacji

Fig. 1. SEM image of base cement slurry (left) and cement slurry with nano- $\mathrm{SiO}_{2}$ (right) after 7 days of hydration

W zaczynach cementowych zawierających dodatek nanocząsteczek niezwykle ważne jest dobranie odpowiedniego współczynnika wodno-cementowego w/c (Li et al., 2004). Przy zbyt niskim współczynniku w/c hydratacja będzie niepełna i spora część ziaren cementu pozostanie nieuwodniona. Nanocząsteczki nie znajdą miejsca na upakowanie się w przestrzeniach porowych, co może powodować tworzenie aglomeratów, które znacznie podniosą lepkość zaczynu. Natomiast przy zbyt dużym współczynniku w/c większa będzie porowatość uzyskana przez twardniejący zaczyn. Część wody zostanie niewykorzystana i w matrycy cementowej powstaną duże pory kapilarne, które nie zostaną zapełnione przez nanokomponenty. 


\section{Badania laboratoryjne zaczynów i kamieni cementowych $\mathrm{z}$ dodatkiem nanokomponentów}

Badania laboratoryjne zaczynów cementowych zawierających dodatek nano- $\mathrm{SiO}_{2}$ wykonywano w Laboratorium Zaczynów Uszczelniających INiG - PIB zgodnie z normami: Przemyst naftowy i gazowniczy - Cementy i materialy do cementowania otworów - Część 1: Specyfikacja (PN-EN ISO 10426-1:2009) oraz Przemyst naftowy i gazowniczy - Cementy i materiaty do cementowania otworów wiertniczych - Częśś 2. Badania cementów wiertniczych (PN-EN ISO 10426-2:2003). W badanych zaczynach cementowych jako spoiwo wiążące zastosowano cement wiertniczy G. Nanokomponent (nano- $\mathrm{SiO}_{2}$ ) dodawano do wody zarobowej i dyspergowano przy użyciu sonifikatora Sonics VC 505 (stosując czas ujednorodniania 5 minut). W badaniach stosowano nano- $\mathrm{SiO}_{2} \mathrm{w}$ proszku Silicon Oxide Nanoparticles/Nanopowder $\left(\mathrm{SiO}_{2}\right.$, średnica 20-30 nm: 99,5\%) o powierzchni właściwej SSA (ang. specific surface area) wynoszacej $200-600 \mathrm{~m}^{2} / \mathrm{g}$ (rys. 2a i 2b).
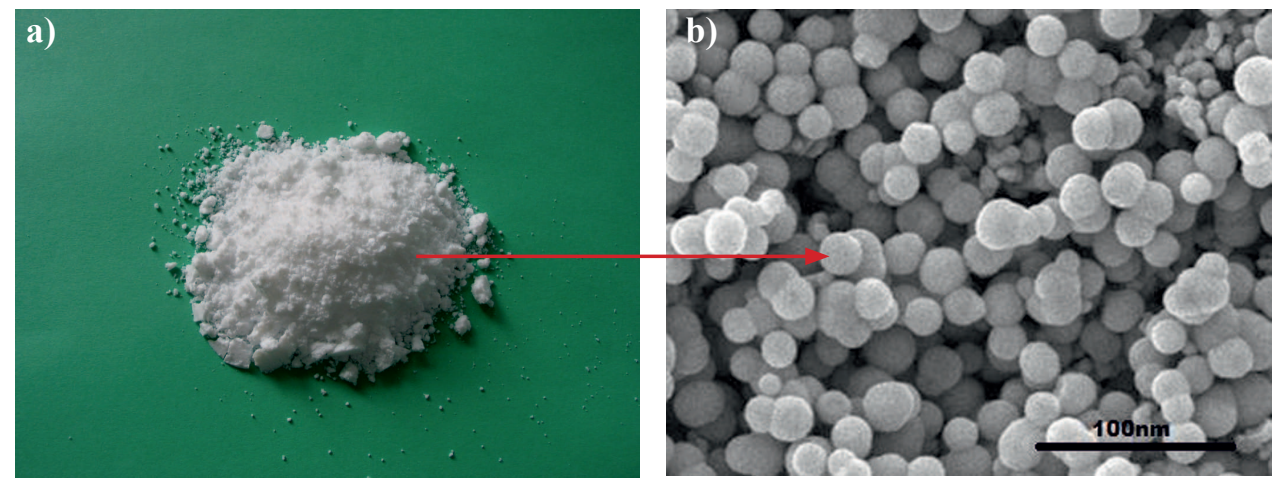

Rys. 2a, b. Po lewej nanokrzemionka nano- $\mathrm{SiO}_{2}$ o średnicy ziaren około 20-30 nm (w postaci proszku) używana w badaniach laboratoryjnych. Po prawej mikrostruktura tejże nanokrzemionki (zdjęcie wykonane pod mikroskopem skaningowym - Katalog SkySpring Nanomaterials). Strzałką zaznaczono pojedynczą cząsteczkę nano- $\mathrm{SiO}_{2}$

Fig. 2a. and 2b. Left: nanosilica (nano- $\mathrm{SiO}_{2}$ ) with a grain diameter of approx. 20-30 nm (in the form of powder) used in laboratory tests. Right: the microstructure of this nanosilica (SEM image). A single nano- $\mathrm{SiO}_{2}$ molecule is marked with an arrow
Podczas prowadzenia testów koncentrowano się na opracowaniu receptur przeznaczonych do uszczelniania kolumn rur okładzinowych w otworach wiertniczych o głębokości końcowej około 1000-2000 metrów. W otworach takich na terenie Polski panuje temperatura denna wynosząca około $40-60^{\circ} \mathrm{C}$. Wstępne badania polegały na odpowiednim doborze wspó1czynnika wodno-cementowego (w/c) oraz ilości dodawanych nanokomponentów. Po przeprowadzeniu szeregu prób uznano, że najkorzystniejsze rezultaty uzyska się, stosując współczynnik w/c na poziomie ok. 0,48 przy ilości nano- $\mathrm{SiO}_{2}$ wynoszacej od $0,5 \%$ do $1 \% \mathrm{w}$ stosunku do masy suchego cementu (mniejsze lub większe ilości nano- $\mathrm{SiO}_{2}$ powodowały pogorszenie parametrów technologicznych zaczynu cementowego).

W tabeli 1 zamieszczono cztery składy zaczynów, zawierających $0,5 \%$ i $1 \%$ nano- $\mathrm{SiO}_{2}$, dla których uzyskano najkorzystniejszy rezultaty. Pierwsze dwa składy sporządzono dla temperatury $40^{\circ} \mathrm{C}$ i ciśnienia $14 \mathrm{MPa}$, a kolejne dwa dla $60^{\circ} \mathrm{C}$ i ciśnienia $21 \mathrm{MPa}$. Zaczyny cementowe przygotowano na bazie wody wodociągowej. Miały one w swym składzie $3 \% \mathrm{KCl}$ oraz powszechnie używane w wiertnictwie dodatki do zaczynów takie jak: upłynniacz (plastyfikator), odpieniacz, środek antyfiltracyjny oraz opóźniacz czasu wiązania. W celu uzyskania odpowiedniego czasu gęstnienia i wiązania w temperaturze $40^{\circ} \mathrm{C}$ należało zastosować 0,05\% opóźniacza czasu wiązania, a w temperaturze $60^{\circ} \mathrm{C}-0,15 \%$ tegoż środka. Wyniki testów zaczynów w warunkach HPHT przedstawia tabela 2. Gęstości badanych receptur wynosiły $1870 \mathrm{~kg} / \mathrm{m}^{3}$, odstoje wody były zerowe, a filtracje uzyskały wartości około $50 \mathrm{~cm}^{3} / 30$ minut

Tabela 1. Składy testowanych zaczynów cementowych

Table 1. Compositions of tested cement slurries

\begin{tabular}{|l|c|c|c|c|}
\hline $\begin{array}{c}\text { Symbol zaczynu, temperatura i ciśnienie / } \\
\text { Skladniki w \% bwoc }\end{array}$ & $\begin{array}{c}\text { Zaczyn A } \\
\left(\mathbf{4 0}{ }^{*} \mathbf{C} / \mathbf{1 4} \mathbf{~ M P a}\right)\end{array}$ & $\begin{array}{c}\text { Zaczyn B } \\
\left(\mathbf{4 0} \mathbf{~}^{\circ} \mathbf{C} \mathbf{1 4} \mathbf{~ M P a}\right)\end{array}$ & $\begin{array}{c}\text { Zaczyn C } \\
\left(\mathbf{6 0}^{\circ} \mathbf{C} / \mathbf{2 1} \mathbf{~ M P a}\right)\end{array}$ & $\begin{array}{c}\text { Zaczyn D } \\
\left.\mathbf{( 6 0} \mathbf{~}^{\circ} \mathbf{C} / \mathbf{2 1} \mathbf{~ M P a}\right)\end{array}$ \\
\hline \hline Woda wodociągowa & 48 & 48 & 48 & 48 \\
\hline Nanokrzemionka n-SiO & 0,5 & 1 & 0,5 & 1,0 \\
\hline $\mathrm{KCl}^{* *}$ & 3,0 & 3,0 & 3,0 & 3,0 \\
\hline Dodatek odpieniający & 0,5 & 0,5 & 0,3 & 0,3 \\
\hline Dodatek upłynniający & 0,3 & 0,3 & 0,2 & 0,2 \\
\hline Dodatek antyfiltracyjny & 0,2 & 0,2 & 0,3 & 0,3 \\
\hline Opóźniacz czasu wiązania & 0,05 & 0,05 & 0,15 & 0,15 \\
\hline Cement wiertniczy G & 100 & 100 & 100 & 100 \\
\hline
\end{tabular}

${ }^{*}$ bwoc - tj. w stosunku do masy suchego cementu. ${ }^{* *} \mathrm{KCl}$ dodawany był w stosunku do masy wody zarobowej (bwow) 
Tabela 2. Parametry zaczynów i kamieni cementowych testowanych w warunkach HPHT

Table 2. Parameters of cement slurries and cement stones tested at HPHT conditions

\begin{tabular}{|c|c|c|c|c|}
\hline $\begin{array}{l}\text { Symbol zaczynu, temperatura i ciśnienie / } \\
\text { Oznaczany parametr }\end{array}$ & $\begin{array}{c}\text { Zaczyn A } \\
\left(40^{\circ} \mathrm{C} / 14 \mathrm{MPa}\right)\end{array}$ & $\begin{array}{c}\text { Zaczyn B } \\
\left(40^{\circ} \mathrm{C} / 14 \mathrm{MPa}\right)\end{array}$ & $\begin{array}{c}\text { Zaczyn C } \\
\left(60^{\circ} \mathrm{C} / 21 \mathrm{MPa}\right)\end{array}$ & $\begin{array}{c}\text { Zaczyn D } \\
\left(60^{\circ} \mathrm{C} / 21 \mathrm{MPa}\right)\end{array}$ \\
\hline Gęstość zaczynu $\left[\mathrm{kg} / \mathrm{m}^{3}\right]$ & 1870 & 1870 & 1870 & 1870 \\
\hline Odstój wody z zaczynu mierzony pod kątem $90^{\circ}[\%]$ & 0,0 & 0,0 & 0,0 & 0,0 \\
\hline Lepkość plastyczna zaczynu $[\mathrm{Pa} \cdot \mathrm{s}]$ & 0,1043 & 0,1058 & 0,1329 & 0,1468 \\
\hline Granica płynięcia zaczynu [Pa] & 3,8 & 4,1 & 5,6 & 6,2 \\
\hline $\begin{array}{l}\text { Czas uzyskania przez zaczyn konsystencji } 30 \mathrm{Bc} \text { w warunkach } \\
\text { HPHT }\end{array}$ & $\begin{array}{l}3 \text { godziny } \\
\text { i } 46 \text { minut }\end{array}$ & $\begin{array}{l}2 \text { godziny } \\
\text { i } 59 \text { minut }\end{array}$ & $\begin{array}{l}3 \text { godziny } \\
\text { i } 22 \text { minuty }\end{array}$ & $\begin{array}{l}2 \text { godziny } \\
\text { i } 39 \text { minut }\end{array}$ \\
\hline $\begin{array}{l}\text { Czas uzyskania przez zaczyn konsystencji } 100 \text { Bc w warun- } \\
\text { kach HPHT }\end{array}$ & $\begin{array}{l}5 \text { godzin } \\
\text { i } 7 \text { minut }\end{array}$ & $\begin{array}{l}4 \text { godziny } \\
\text { i } 10 \text { minut }\end{array}$ & $\begin{array}{l}3 \text { godziny } \\
\text { i } 47 \text { minut }\end{array}$ & $\begin{array}{l}3 \text { godziny } \\
\text { i } 4 \text { minuty }\end{array}$ \\
\hline Filtracja zaczynu w warunkach HPHT $\left[\mathrm{cm}^{3} / 30 \mathrm{~min}\right]$ & 54 & 46 & 52 & 46 \\
\hline $\begin{array}{l}\text { Wytrzymałość na ściskanie kamienia cementowego po } 48 \text { go- } \\
\text { dzinach hydratacji (pomiar z aparatu UCA) [MPa] }\end{array}$ & 27,4 & 31,2 & 25,3 & 28,9 \\
\hline $\begin{array}{l}\text { Czas do uzyskania wczesnej wytrzymałości na ściskanie wyno- } \\
\text { szącej } 3,5 \mathrm{MPa}\end{array}$ & $\begin{array}{l}10 \text { godzin } \\
\text { i } 6 \text { minut }\end{array}$ & $\begin{array}{l}12 \text { godzin } \\
\text { i } 55 \text { minut }\end{array}$ & $\begin{array}{l}13 \text { godzin } \\
\text { i } 52 \text { minuty }\end{array}$ & $\begin{array}{l}7 \text { godzin } \\
\text { i } 30 \text { minut }\end{array}$ \\
\hline $\begin{array}{l}\text { Wytrzymałość na ściskanie kamienia cementowego po } 28 \\
\text { dniach hydratacji [MPa] }\end{array}$ & 34,4 & 37,1 & 36,4 & 38,7 \\
\hline Przyczepność do rur stalowych po 28 dniach hydratacji [MPa] & 5,7 & 5,9 & 6,2 & 6,4 \\
\hline $\begin{array}{l}\text { Udział porów o średnicy powyżej } 10000 \mathrm{~nm} \text { w całej matrycy } \\
\text { kamienia cementowego [\%] }\end{array}$ & 2,7 & 2,0 & 1,4 & 2,8 \\
\hline $\begin{array}{l}\text { Udział porów o średnicy } 100-10000 \mathrm{~nm} \text { w całej matrycy ka- } \\
\text { mienia cementowego [\%] }\end{array}$ & 0,7 & 1,4 & 0,3 & 2,1 \\
\hline $\begin{array}{l}\text { Udział porów o średnicy poniżej } 100 \mathrm{~nm} \text { w całej matrycy ka- } \\
\text { mienia cementowego [\%] }\end{array}$ & 96,6 & 96,6 & 98,3 & 95,1 \\
\hline
\end{tabular}

(w przypadku zwiększonej ilości nano- $\mathrm{SiO}_{2}$ zanotowano nieznaczne obniżenie wartości filtracji). Czasy gęstnienia zaczynów regulowano w ten sposób, aby osiągnąc możliwość bezpiecznego przepompowania płynnej receptury do przestrzeni pierścieniowej otworu wiertniczego (czasy te wynosiły od około 3 godzin do około 5 godzin). Wykresy przedstawiające przebieg procesu gęstnienia zaczynów wraz z upływem czasu zamieszczono na rysunkach od 3 do 7 . Niebieskie krzywe obrazują przebieg zmiany konsystencji zaczynów w jednostce Bc (PN-EN ISO 10426-2:2003). Próbki zaczynów cementowych poddano badaniom także na aparacie UCA (ultrasonograficznym analizatorze cementu) przez okres 48 godzin. Dzięki temu badaniu uzyskano szereg informacji na temat narastania wczesnej wytrzymałości mechanicznej powstających kamieni cementowych w symulowanych warunkach otworowych. Wyniki badań zamieszczono w tabeli 2 oraz na rysunkach od 5 do 8 (zielone krzywe na rysunkach obrazują narastanie wczesnej wytrzymałości na ściskanie). Można zauważyć, że badane receptury osiągają (w zależności od receptury i składu) wczesną wytrzymałość na ściskanie na poziomie 3,5 MPa po czasie około 71/22 godziny do 14 godzin. Osiągnięcie przez kamień cementowy wartości wczesnej wytrzymałości na ściskanie równej 3,5 MPa pozwala na wykonywanie dalszych prac w otworze. Po 48 godzinach wartości wytrzymałości na ściskanie rosną, osiągając około 25-27 MPa dla próbek z dodatkiem $0,5 \%$ nano- $\mathrm{SiO}_{2}$ oraz ok. 29-31 MPa dla próbek z 1\% nano-SiO ${ }_{2}$. Po sporządzeniu i utwardzeniu kostek kamieni cementowych uzyskano wyniki wytrzymałości na ściskanie po 28 dniach hydratacji. Dla próbek z dodatkiem $0,5 \%$ nano- $\mathrm{SiO}_{2}$ wytrzymałość na ściskanie wynosiła około $35 \mathrm{MPa}$, natomiast dla próbek z $1 \%$ nano- $\mathrm{SiO}_{2}$ - około $38 \mathrm{MPa}$. Przyczepność do rur stalowych po 28 dniach hydratacji była bardzo wysoka i wyniosła około $6 \mathrm{MPa}$. Na uwagę zasługują także niezwykle korzystne parametry mikrostruktury powstałej z zaczynów cementowych zawierających nanokomponenty. W testowanych próbkach udział porów o średnicy powyżej $10000 \mathrm{~nm}$ w całej matrycy kamienia cementowego wynosił zalewie około $2 \%$, natomiast udział porów o średnicy poniżej $100 \mathrm{~nm}$ - aż około 95-98\%. Świadczy to o tym, że matryca cementowa zagęszczona przez nano- $\mathrm{SiO}_{2}$ jest niezwykle szczelna.

Trudno jest bezpośrednio porównać parametry uzyskane dla zaczynów opisanych wyżej z parametrami, jakie posiadają zaczyny konwencjonalne, głównie dlatego, że wprowadzenie dodatku nanocząsteczek wiąże się ze zmianą składu receptury (między innymi zmianą współczynnika w/c, ilości 
upłynniacza i innych). Generalnie receptury konwencjonalne posiadają znacznie większą filtrację i odstój wody w porównaniu do zaczynów z nano- $\mathrm{SiO}_{2}$. Oprócz tego kamień cementowy

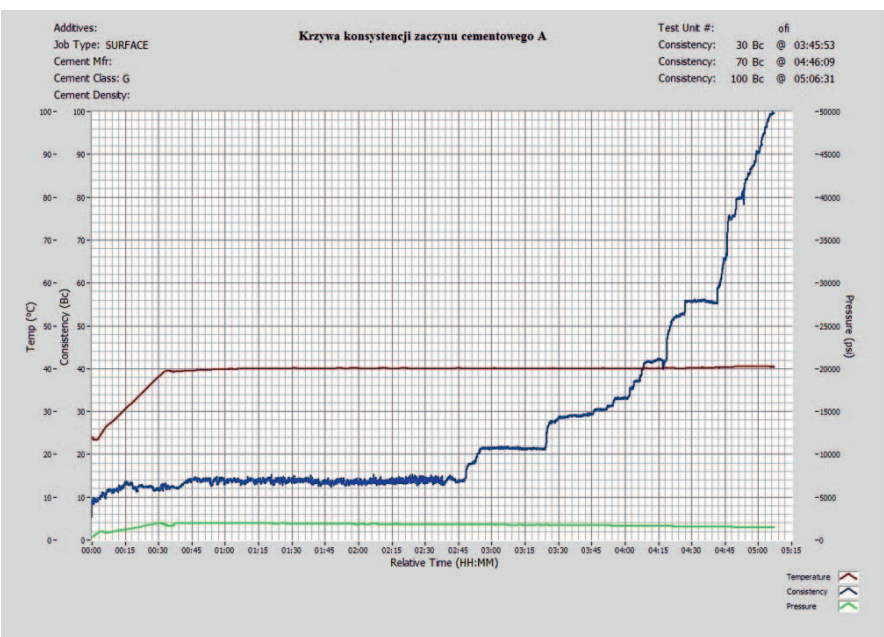

Rys. 3. Krzywa konsystencji zaczynu cementowego A

Fig. 3. Consistency curve of cement slurry A

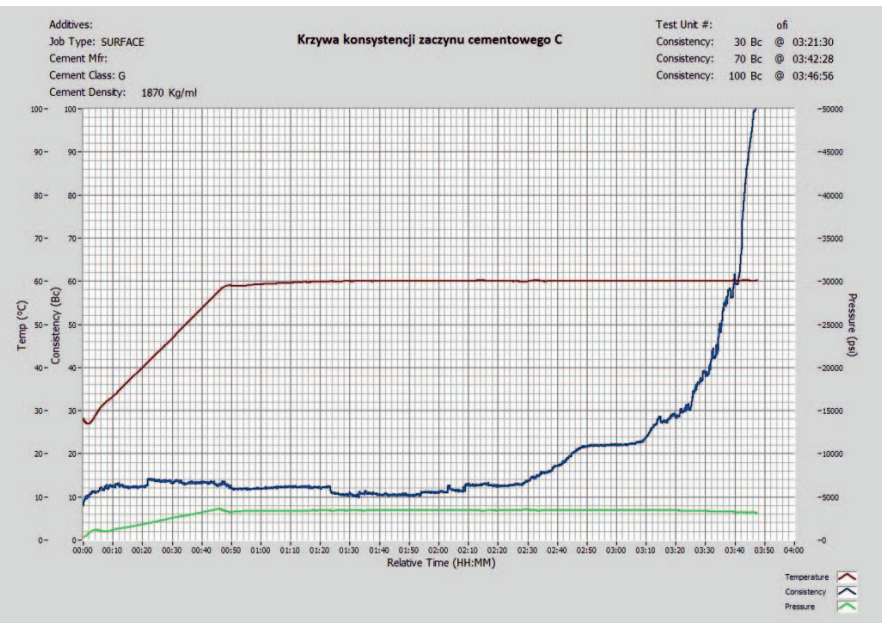

Rys. 5. Krzywa konsystencji zaczynu cementowego $C$

Fig. 5. Consistency curve of cement slurry $\mathrm{C}$

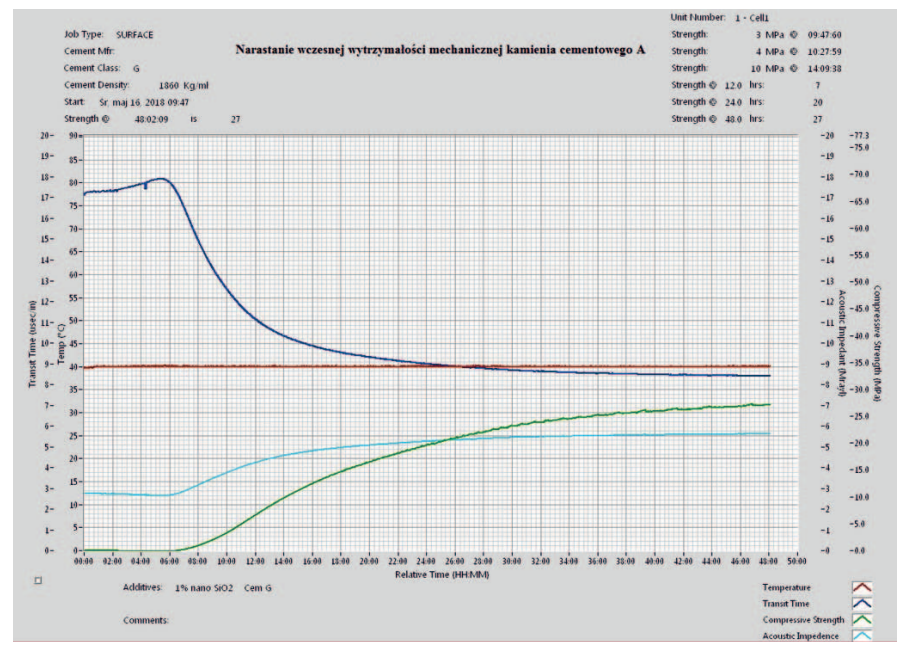

Rys. 7. Narastanie wczesnej wytrzymałości mechanicznej próbki A

Fig. 7. Development of early-age compressive strength of sample A powstały z zaczynów konwencjonalnych jest wyraźnie słabszy, a struktura znacznie mniej zwarta niż w zaczynach zawierających nanokomponenty.

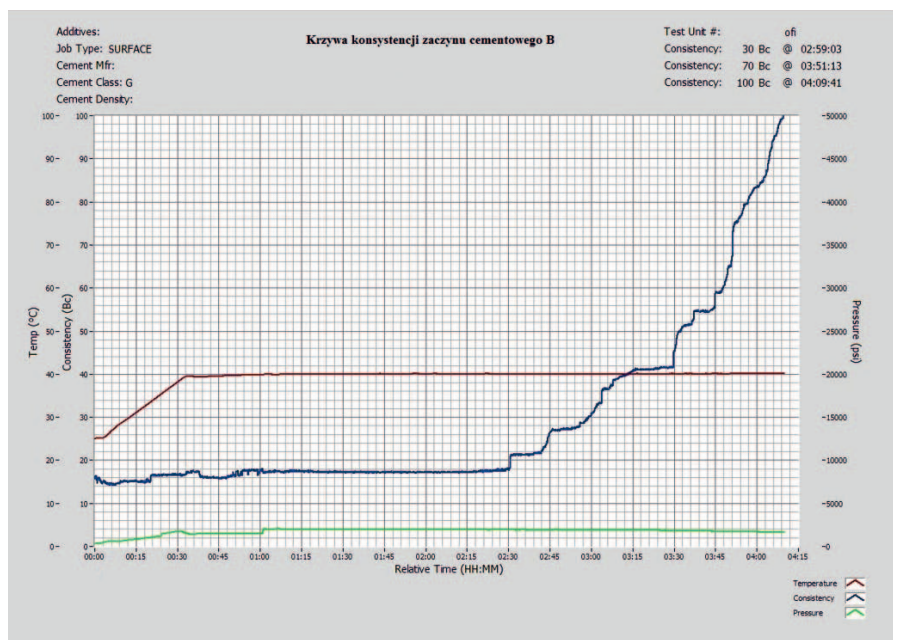

Rys. 4. Krzywa konsystencji zaczynu cementowego B

Fig. 4. Consistency curve of cement slurry B

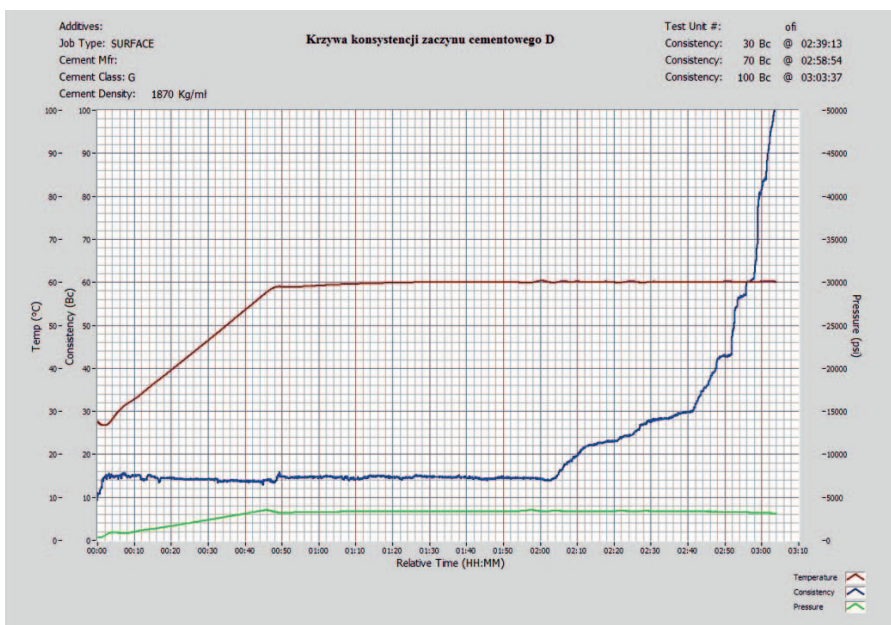

Rys. 6. Krzywa konsystencji zaczynu cementowego D

Fig. 6. Consistency curve of cement slurry D

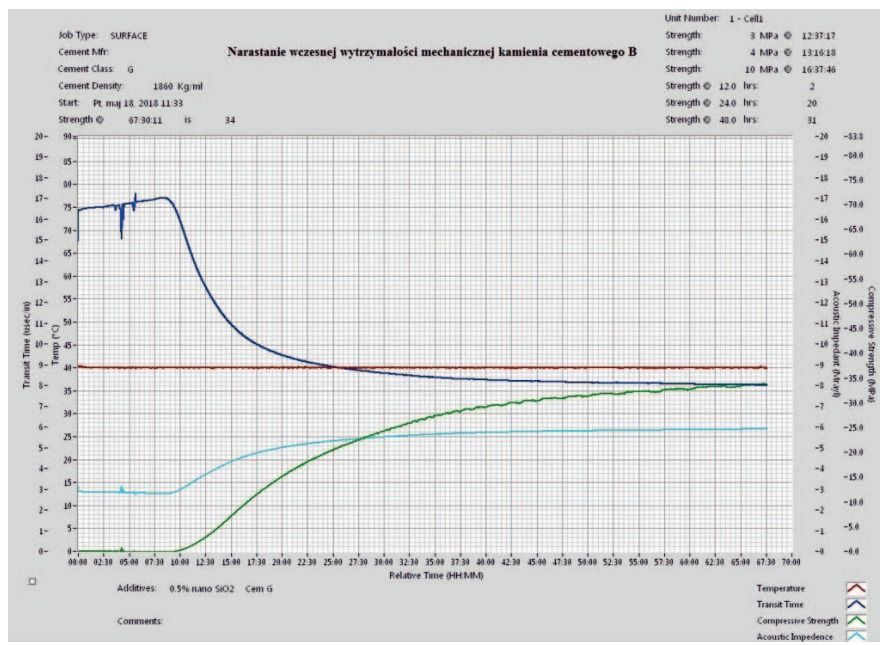

Rys. 8. Narastanie wczesnej wytrzymałości mechanicznej próbki B Fig. 8. Development of early-age compressive strength of sample B 


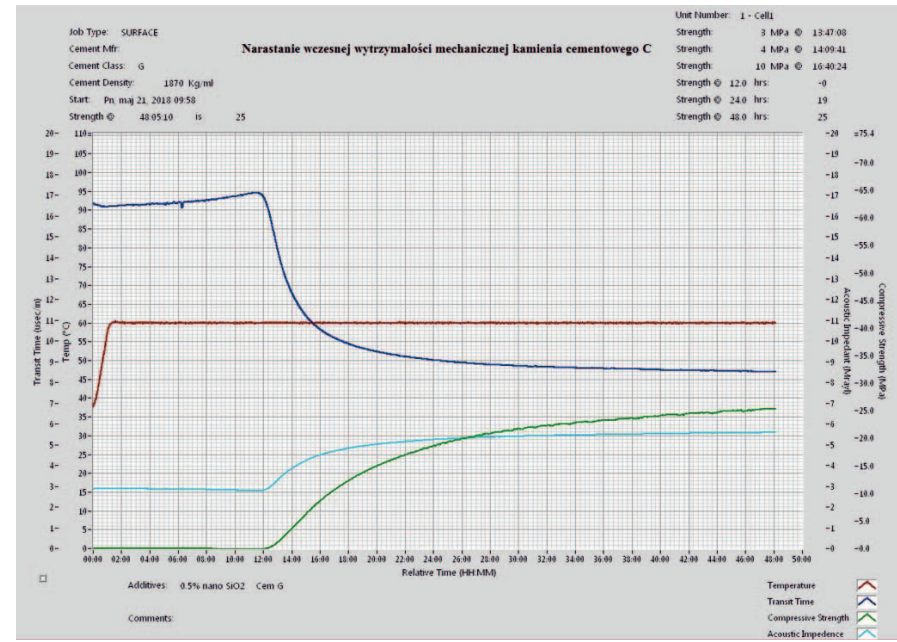

Rys. 9. Narastanie wczesnej wytrzymałości mechanicznej próbki $\mathrm{C}$

Fig. 9. Development of early-age compressive strength of sample $\mathrm{C}$

Potwierdzeniem niezwykle zwartej mikrostruktury próbek z nano- $\mathrm{SiO}_{2}$ mogą być rysunki stwardniałych próbek zaczynów wykonane za pomocą mikroskopii skaningowej. $\mathrm{Na}$ rysunkach 11a i 11b (powiększenie 1000-krotne) widoczne są przeciętne mikrostruktury zaczynu konwencjonalnego, tj. bez dodatku nanokomponentów. Można tam dostrzec pory o dość dużych rozmiarach, które po połączeniu się ze sobą mogą tworzyć kanaliki w płaszczu cementowym i powodować ewentualny przepływ gazu w przestrzeni pierścieniowej

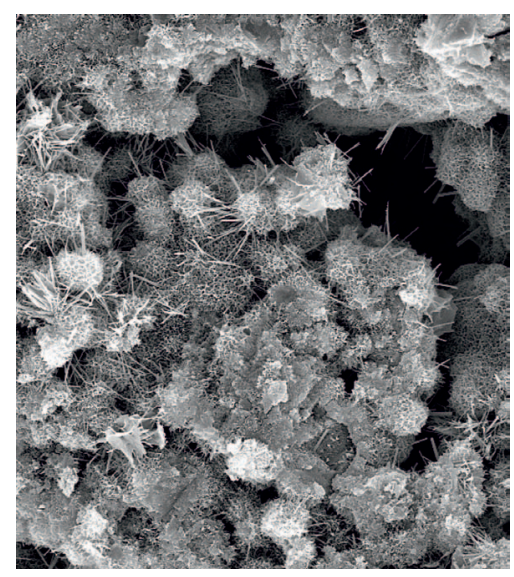

Rys. 11a. Przykładowa mikrostruktura zaczynu cementowego „konwencjonalnego" (bez dodatku nanokomponentów). Powiększenie 1000-krotne Fig. 11a. An example of microstructure of a ,conventional" cement slurry (without the addition of nanocomponents). Magnification 1000x

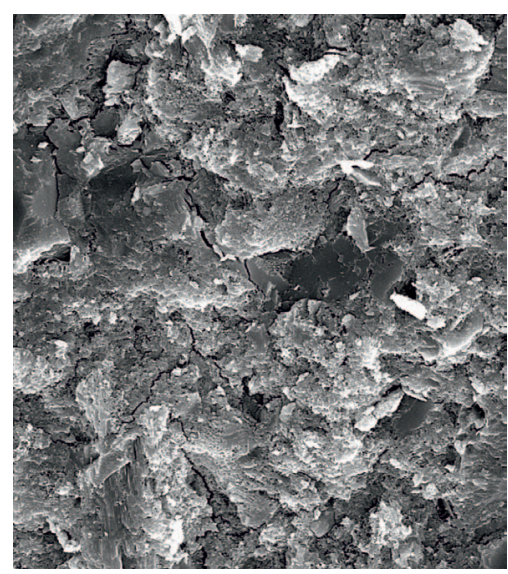

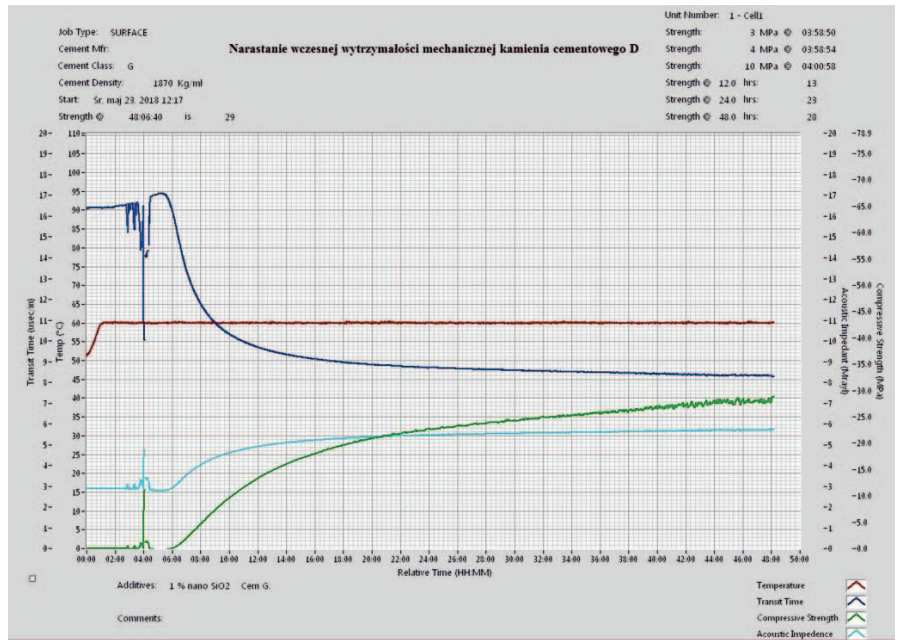

Rys. 10. Narastanie wczesnej wytrzymałości mechanicznej próbki D Fig. 10. Development of early-age compressive strength of sample D

otworu wiertniczego. Po wprowadzeniu do próbki 1\% nanokrzemionki (nano- $\mathrm{SiO}_{2}$ ) struktura stwardniałego zaczynu uległa znacznemu zagęszczeniu (rys. 12a i 12b). Na rysunkach widać, że zmodyfikowana nanokomponentami matryca cementowa jest znacznie bardziej zwarta w porównaniu do matrycy wytworzonej przez zaczyn konwencjonalny (na rysunkach 12a i 12 b nie występują obszary makroporów). Ponadto stwardniały zaczyn zmodyfikowany nanokomponentami wykazuje bardzo wysoką szczelność oraz niewielką porowatość.

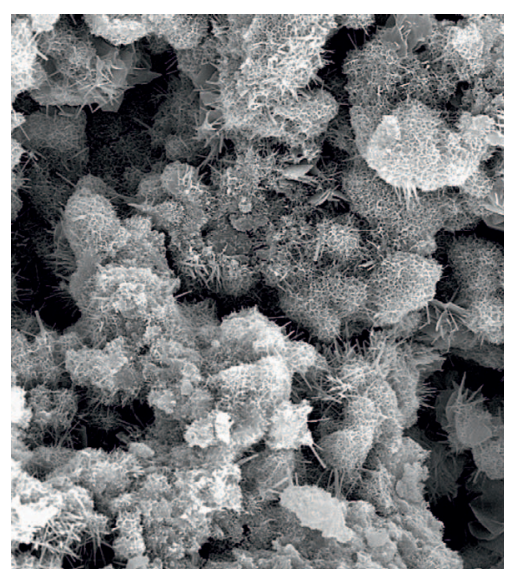

Rys. 11b. Przykładowa mikrostruktura zaczynu cementowego ,konwencjonalnego" (bez dodatku nanokomponentów). Powiększenie 1000-krotne

Fig. 11b. An example of microstructure of a ,conventional" cement slurry (without the addition of nanocomponents). Magnification 1000x

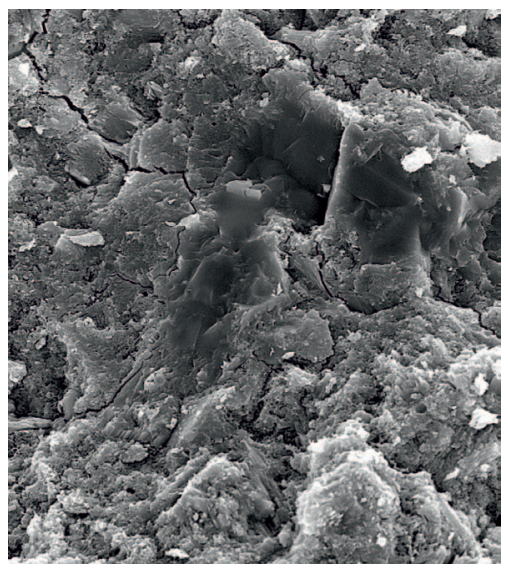

Rys. 12b. Przykładowa mikrostruktura zaczynu cementowego zawierającego $1 \%$ nano- $\mathrm{SiO}_{2}$. Powiększenie 1000-krotne Fig. 12b. An example of microstructure of a cement slurry containing $1 \%$ of nano- $\mathrm{SiO}_{2}$. Magnification 1000x 


\section{Podsumowanie}

Zaprezentowane w niniejszym artykule zaczyny cementowe $\mathrm{z}$ dodatkiem nanocząsteczek krzemu (nano- $\mathrm{SiO}_{2}$ ) mogą być podstawą do opracowania szerokiej gamy innowacyjnych receptur zaczynów przeznaczonych od uszczelniania otworów wiertniczych o głębokości ok. 1000-2000 metrów, w których wymagane jest osiągnięcie bardzo wysokiej szczelności matrycy cementowej.

Analizując uzyskane wyniki badań laboratoryjnych wpływu nanomateriałów na właściwości zaczynu cementowego, można stwierdzić, że komponenty te powodują poprawę parametrów płynnego i stwardniałego zaczynu cementowego. Na szczególną uwagę zasługuje fakt, że kamienie cementowe otrzymane z zaczynów zawierających nanokomponenty charakteryzowały się wysokimi wartościami wytrzymałości na ściskanie, co jest spowodowane upakowaniem się w przestrzeniach porowych nanocząsteczek o bardzo małych rozmiarach.

Na podstawie uzyskanych wyników można stwierdzić, że:

- najkorzystniejsze parametry technologiczne otrzymano dla zaczynów cementowych zawierających około 0,5-1\% nano- $\mathrm{SiO}_{2}$ (większe lub mniejsze ilości nanokomponentów nie wpływały na poprawę parametrów technologicznych świeżych i stwardniałych zaczynów cementowych);

- przy zastosowaniu 0,5-1\% nano- $\mathrm{SiO}_{2}$ optymalny współczynnik wodno-cementowy kształtował się na poziomie około 0,48 ;

- próbki z nanokomponentami posiadały bardzo niską (około 2\%) zawartość porów kapilarnych, mogących tworzyć kanaliki dla przepływu mediów złożowych przez płaszcz cementowy w otworze wiertniczym. Pory o najmniejszych rozmiarach (poniżej $100 \mathrm{~nm}$ ) stanowią zdecydowaną większość (powyżej 95\%) ogólnej ilości porów występujących w matrycy cementowej. Świadczy to o bardzo niskiej przepuszczalności dla medium złożowego w przypadku zastosowania próbek z dodatkami nanokomponentów;

- czasy gęstnienia badanych zaczynów z dodatkiem nanokomponentów w temperaturach od $40^{\circ} \mathrm{C}$ do $60^{\circ} \mathrm{C}$ można z powodzeniem regulować za pomocą powszechnie dostępnych środków opóźniających;

- wartość wczesnej wytrzymałości na ściskanie równą 3,5 MPa rejestrowano za pomocą aparatu UCA. Zaczyny uzyskiwały ją po czasach od około 71/2 godziny do 14 godzin. Po tym okresie kamień cementowy jest na tyle mocny, że możliwe jest dalsze prowadzenie prac w otworze;

- wartości wczesnych wytrzymałości na ściskanie badane na UCA dochodziły niekiedy nawet do $30 \mathrm{MPa}$ po 48 godzinach (co w przypadku zaczynów konwencjonalnych jest niezwykle trudne do uzyskania);
- wytrzymałości na ściskanie po 28 dniach hydratacji przyjmowały wysokie wartości. Dla próbek z dodatkiem $0,5 \%$ nano- $\mathrm{SiO}_{2}$ wynosiły one około 34-36 MPa, a z dodatkiem $1 \%$ nano- $\mathrm{SiO}_{2}$ - około 37-39 $\mathrm{MPa}$;

- przyczepności do rur stalowych kamieni cementowych z nanokomponentami były bardzo wysokie. Dla próbek z 0,5\% nano- $\mathrm{SiO}_{2}$ wynosiły około 5,5-6 MPa, a z dodatkiem $1 \%$ nano-SiO - powyżej $6 \mathrm{MPa}$.

Artykuł powstał na podstawie prac statutowych pt.: Zaczyny cementowe o krótkich czasach żelowania i wiazania do uszczelniania plytkich otworów wiertniczych - praca INiG - PIB na zlecenie MNiSW; nr zlecenia: 0017/KW/2018, nr archiwalny: DK-41000017/2018, oraz Analiza wpływu dodatków nanoczasteczek na mikrostrukturę stwardniatych zaczynów cementowych - praca INiG - PIB na zlecenie MNiSW; nr zlecenia: 0041/KW/2016, nr archiwalny: DK-4100-0041/2016.

\section{Literatura}

Biricik H., Sarier N., 2014. Comparative study of the characteristics of nano silica - silica fume - and fly ash - incorporated cement mortars. Materials Research, 17: 570-582. DOI: 10.1590/ s1516-14392014005000054.

De la Roij R., Egyed C., Lips J.P., 2012. Nano-Engineered Oil Well Cement Improves Flexibility And Increases Compressive Strength: A Laboratory Study. Society of Petroleum Engineers. DOI: $10.2118 / 156501-\mathrm{MS}$.

Dębińska E., 2014. Wpływ nanokrzemionki na parametry mechaniczne kamienia cementowego. Nafta-Gaz, 4: 229-235.

Dębińska E., 2015. Niekonwencjonalne zaczyny cementowe $\mathrm{z}$ dodatkiem nanokrzemionki. Nafta-Gaz, 5: 290-300.

Dębińska E., Rzepka M., Kremieniewski M., 2016. Nanocząsteczki - nowa droga w kształtowaniu parametrów świeżych i stwardniałych zaczynów cementowych. Nafta-Gaz, 12: 1084-1091. DOI: 10.18668/NG.2016.12.11.

Ershadi V., Ebadi T., 2011. The Effect of Nanosilica on Cement Matrix Permeability in Oil Well to Decrease the Pollution of Receptive Environment. International Journal of Environmental Science and Development, 2: 128-132. DOI: 10.7763/IJESD.2011.V2.109.

Horszczaruk E., Mijowska E., Cendrowski K., Mijowska S., Sikora P., 2013. Wpływ nanokrzemionki o zróżnicowanej morfologii na właściwości mechaniczne zapraw cementowych. Cement Wapno Beton, 1: 24-32.

Katalog SkySpring Nanomaterials, Inc. $<$ https://www.ssnano.com/inc/ sdetail/silicon_oxide_nanoparticles_nanopowder_treated_with_ silane_couplig_agents_sio2_99_/209> (dostęp: 10.09.2018).

Li H., Xiao H., Ou J., 2004. Microstructure of Cement Mortar with Nano-Particles. Composites Part B: Engineering, 35: 185-189. DOI: $10.1016 / \mathrm{S} 1359-8368(03) 00052-0$.

Mondal P., Shah S.P., Marks L.D., Gaitero J.J., 2010. Comparative Study of the Effects of Microsilica and Nanosilica in Concrete. Transportation Research Record: Journal of the Transportation Research Board, 2141: 6-9. DOI: 10.3141/2141-02.

Patil R., Deshpande A., 2012. Use of Nanomaterials in Cementing Applications. Society of Petroleum Engineers. DOI: 10.2118/155607-MS.

Santra A., Boul P.J., Pang X., 2012. Influence of Nanomaterials in Oilwell Cement Hydration and Mechanical Properties. Society of Petroleum Engineers. DOI: 10.2118/156937-MS. 
Uliasz M., Zima G., Błaż S., Jasiński B., 2015. Ocena właściwości cieczy wiertniczych $\mathrm{w}$ aspekcie zapobiegania migracji gazu w otworach na przedgórzu Karpat. Nafta-Gaz, 1: 11-17.

Wilk K., Kasza P., Czupski M., 2014. Zastosowanie nanocieczy jako dodatków wspomagających proces wypierania ropy naftowej. Nafta-Gaz, 1: 14-20.

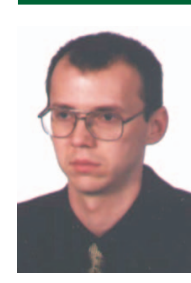

Dr inż. Marcin RZEPKA

Kierownik Laboratorium Zaczynów Uszczelniających w Zakładzie Technologii Wiercenia

Instytut Nafty i Gazu - Państwowy Instytut Badawczy

ul. Lubicz 25 A

31-503 Kraków

E-mail:marcin.rzepka@inig.pl

\section{Akty prawne i normatywne}

PN-EN ISO 10426-1:2009 Przemyst naftowy i gazowniczy - Cementy i materiały do cementowania otworów - Część 1: Specyfikacja.

PN-EN ISO 10426-2:2003 Przemyst naftowy i gazowniczy - Cementy i materialy do cementowania otworów wiertniczych-Część 2: Badania cementów wiertniczych.
Mgr inż. Miłosz KĘDZIERSKI

Specjalista inżynieryjno-techniczny w Zakładzie

Technologii Wiercenia

Instytut Nafty i Gazu - Państwowy Instytut Badawczy ul. Lubicz 25 A

31-503 Kraków

E-mail: milosz.kedzierski@inig.pl

\section{OFERTA BADAWCZA ZAKKADU TECHNOLOGII WIERCENIA}

opracowywanie składów i technologii sporządzania ptuczek wiertniczych, cieczy do dowiercania, opróbowania i rekonstrukcji odwiertów, zaczynów cementowych i mieszanin wiążących dla różnych warunków geologiczno-technicznych wiercenia;

- kompleksowe badania i ocena nowych rodzajów środków chemicznych, materiatów ptuczkowych i wiążących, przeznaczonych do sporządzania i regulowania wtaściwości płuczek wiertniczych i zaczynów cementowych;

- pomiary parametrów technologicznych cieczy wiertniczych i kamienia cementowego w warunkach HPHT;

- badania wptywu cieczy wiertniczych na przewiercane skaty;

- dobór ptuczek wiertniczych, zaczynów cementowych, cieczy buforowych w celu poprawy skuteczności cementowania otworów wiertniczych;

badania serwisowe dla bieżących zabiegów cementowania;

specjalistyczne badania laboratoryjne dotyczące oznaczania: wspótczynnika tarcia cieczy wiertniczych i napięcia powierzchniowego na granicy faz, czystości i temperatury krystalizacji solanek, typu emulsji, sedymentacii fazy stałej, efektywności wynoszenia zwiercin w otworach kierunkowych i poziomych oraz wyptukiwania osadów itowych ze skat przed zabiegiem cementowania, odporności na migracje gazu w wiążącym zaczynie cementowym w warunkach otworopodobnych, wczesnej wytrzymałośc na ściskanie kamienia cementowego, odporności korozyjnej kamienia cementowego w różnym środowisku złożowym, porowatości oraz przepuszczalności dla gazu kamienia cementowego i skat, zawartości związków chemicznych w cieczach wiertniczych, stopnia toksyczności środków chemicznych i cieczy wiertniczych przy użyciu bioindykatorów;

· badania właściwości fizyczno-mechanicznych skał pod kątem ich zwiercalności.

Kierownik: dr inż. Małgorzata Uliasz Adres: ul. Armii Krajowej 3, 38-400 Krosno Telefon: 134368941 w. 5219 Faks: 134367971 E- mail: malgorzata.uliasz@inig.pl

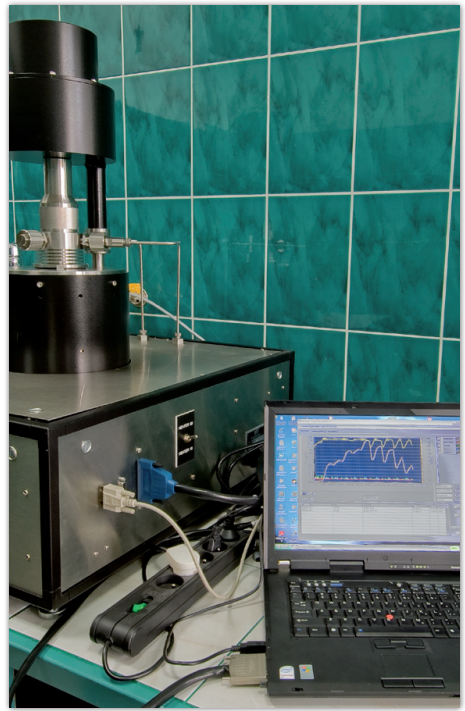

INSTYTUT NAFTY I GAZU - Państwowy Instytut Badawczy 